\title{
Evaluation of GeneXpert for Quantification Viral Load Hepatitis C Virus
}

\author{
Chyntia Olivia Maurine Jasirwan, Irsan Hasan, Andri Sanityoso Sulaiman, \\ Rino Alvani Gani \\ Division of Hepatobiliary, Department of Internal Medicine, Faculty of Medicine, \\ Universitas Indonesia/Dr. Cipto Mangunkusumo National General Hospital, Jakarta
}

\section{Corresponding Author:}

Chyntia Olivia Maurine Jasirwan. Division of Hepatobiliary Division, Department of Internal Medicine, Dr. Cipto Mangunkusumo National General Hospital. Jl. Diponegoro No. 71 Jakarta Indonesia. Phone: +62-2131900924; facsimile: +62-21-3918842.Email: chynmadu@gmail.com.

\begin{abstract}
Background: GeneXpert has been used for Mycobacterium tuberculosis testing, but is currently available for Hepatitis c virus (HCV) RNA testing. GeneXpert assay is expected to be more accurate, efficient, and costeffective for HCV viral load quantification. This study intended to evaluate the new method quantification of plasma HCV RNA by the GeneXpert in comparison to the Roche Cobas TaqMan 96 as standard diagnostic tools.

Method: A total of $54 \mathrm{HCV}$-infected plasma samples with anti-HCV positive were examined by GeneXpert assay, followed with Cobas TaqMan 96 for quantification of HCV RNA. Correlation was performed by Pearson test (in $\left.\log _{10}\right)$ and diagnostic test by Chi-square test. Sensitivity and specificity of the GeneXpert assay measured by calculating $2 \times 2$ contingency table. Bland-Altman plot were generated to assess the mean difference between the two assays.

Results: GeneXpert has strong correlation to the Roche Cobas TaqMan $96(R=0.993 ; p=0.001)$. GeneXpert has sensitivity of 100\% (95\% CI: 90-100\%) and specificity of $90 \%$ (95\% CI: $54.1-99.5 \%)$. The Bland Altmand plot showed that one sampel has 1 log difference with the Roche Cobas TaqMan 96 measurement result.

Conclusion: There was a strong correlation in the measurement of HCV RNA by GeneXpert and moreover its assay also has an excellent overall performance compared to Cobas TaqMan 96. Thus, it can be considered as a reliable tools for HCV virological response monitoring.
\end{abstract}

Keywords: Hepatitis c virus (HCV) viral load testing, GeneXpert, Cobas TaqMan 96

\section{ABSTRAK}

Latar belakang: Genexpert telah digunakan untuk pemeriksaan Mycobacterium tuberculosis, namun saat ini tersedia untuk pemeriksaan RNA virus Hepatitis C. Pemeriksaan menggunakan GeneXpert diharapkan dapat mengeluarkan hasil kuantifikasi virus Hepatitis Cyang lebih akurat, efisien, dan hemat biaya. Studi ini bertujuan untuk mengevaluasi metode baru untuk menghitung plasma RNA Virus Hepatitis C dengan menggunakan GeneXpert dibandingkan dengan Roche Cobas TaqMan 96 sebagai alat diagnostik standar.

Metode: Sebanyak 54 sampel plasma Hepatitis $C$ dengan anti-HCV positif dilakukan pemeriksaan menggunakan GeneXpert, yang kemudian diikuti dengan pemeriksaan menggunakan Cobas TaqMan 96 untuk mendapatkan kuantifikasi RNA virus Hepatitis C. Korelasi dilakukan dengan uji Pearson $\left(\log _{10}\right)$ dan uji diagnostik dilakukan dengan Chi Square test. Sensitifitas dan spesifisitas uji GeneXpert dihitung dengan menggunakan tabel kontingensi 2x2. Plot Bland-Altman ditampilkan untuk menilai perbedaan rata-rata antara kedua alat pemeriksaan. 
Hasil: GeneXpert mempunyai korelasi yang kuat dengan Roche Cobas TaqMan $96(R=0.993 ; p=0.001)$. GeneXpert mempunyai sensitivitas sebesar 100\% (95\% CI: 90-100\%) dan spesifisitas sebesar 90\% (95\% CI: 54.1-99.5\%). Plot Bland Altmand menunjukan bahwa terdapat satu sampel yang memiliki perbedaan 1 log dengan hasil pemeriksaan menggunakan Roche Cobas TaqMan 96.

Kesimpulan: Terdapat korelasi yang kuat pada pemeriksaan RNA Hepatitis C menggunakan GeneXpert dan terdapat performa Genexpert yang lebih baik dibandingkan dengan Cobas TaqMan 96. Dengan demikian, Genexpert dapat dianggap sebagai alat yang handal untuk dapat digunakan sebagai alat pemantauaun virologis Hepatitis $C$.

\section{Kata Kunci: Tes jumlah virus Hepatitis C, GeneXpert, Cobas TaqMan 96}

\section{INTRODUCTION}

Hepatitis $\mathrm{C}$ virus (HCV) infection is one of the leading causes of chronic liver disease in the world. An estimated three to four million people globally are newly infected each year; 180 million are chronically infected; and about 350,000 people are die due to $\mathrm{HCV}$ related disease. ${ }^{1,2}$ South and Southeast Asia regions have a moderate prevalence of HCV infection (1.5$3.5 \%$ ). Regardless of the prevalence and opportunities to be treated, only a small number of people in low- and middle-income countries (LMIC) have a chance or access to the testing facilities. ${ }^{3}$

Diagnosis of HCV infection consists of initial screening with serological assay, anti-HCV antibodies. Besides of the baseline levels measurement, HCVinfected patients should also undergo a treatment response monitoring by HCV RNA quantification. These long pathway requires multiple visits. For that reason, an accurate, efficient, and cost-effective diagnostic testing are needed to improve patients' compliance in $\mathrm{HCV}$ infection diagnosis and therapy monitoring., ${ }^{4,5}$ HCV RNA quantification is a confirmatory testing for anti-HCV antibodies result. HCV RNA has superiority against anti-HCV antibodies measurement because its ability to detect the viral infection during anti-HCV seroconversion period (window period around 66 days). Quantification of HCV RNA also minimize false negative result in the diagnosis of $\mathrm{HCV}$ in special population, e.g. immunodeficient patient. Thus, viral load is crucial parameter in detection and monitoring of $\mathrm{HCV}$ infection at all condition. .,6,7 $^{-6}$

The Xpert HCV viral load finger-stick (Xpert HCV VL FS), developed by Cepheid is an interesting finding. Study by Lamoury et al shown that Xpert HCV VL FS has good sensitivity and specificity, and it has high degree of correlation compared to the Abbott RealTime Viral Load assay. ${ }^{5}$ Gupta et al, demonstrate a good correlation between Xpert and Abbott assay and the turn-around time of Xpert has shorter. ${ }^{8}$ The GeneXpert has been widely used in Indonesia for tuberculosis testing. Its availability across the country is broader compared to more advanced HCV RNA quantification tools. GeneXpert is WHO qualified device for measuring HCV RNA viral load. This tool quantify HCV RNA by automated reverse transcriptase polymerase chain reaction (RT-PCR) method. ${ }^{9}$ Despite of its privilege, in Indonesia, this tools has not been utilized optimally for $\mathrm{HCV}$ infection virological response monitoring. GeneXpert assay is new diagnostic tools for quantifies HCV RNA in our center which expected to be more accessible for $\mathrm{HCV}$ response therapy monitoring in areas of remoteness or limited facilities of LMIC as in Indonesia. Aim of this study is to testing whether the GeneXpert can be used for quantitative detection of $\mathrm{HCV}$ viral load compared to existing gold standard tools: Roche Cobas TaqMan 96.

\section{METHOD}

This study was conducted in the Division of Hepatobiliary, Department of Internal Medicine, Cipto Mangunkusumo National Hospital, Indonesia, between March and November 2017. Each participant has been given their consent prior to the study. All study procedures were approved by the FKUI-RSCM (Faculty of Medicine, Universitas Indonesia - Cipto Mangunkusumo National Hospital) Research Ethical Committee with protocol number 17-07-0707. The inclusion criteria to this study were adult patients aged 18 years or older with HCV infection marked by positive anti-HCV antibodies results.

Up to 45 from total $54 \mathrm{HCV}$-infected patients with anti-HCV positive and detectable viral load quantification from inpatients and ambulatory clinic of the General Hospital were recruited in this study. Up to 9 from total 54 post treatment samples, with undetectable viral load RNA samples, were 
also include to this study as control, so we can run diagnostic tools for examined sensitifity and specifity of GeneXpert assay. These patients were selected using convenience sampling method and were provided information about the study. As much as $9 \mathrm{~mL}$ plasma speciment were then collected from peripheral veins. All plasma samples examined by two different assays: Roche Cobas TaqMan 96, as a standard diagnostic tool, and GeneXpert.

As many as $650 \mu \mathrm{L}$ plasma inserted into the sample tubes provided by manufacturer and loading them into the machine. The samples underwent extraction according to manufacturers' instruction for about 60 minutes and followed by polymerase chain reaction (PCR) for about 120 minutes. The results were obtained in approximately 3 hours.

As many as $1000 \mathrm{uL}$ plasma inserted into the singleuse disposable cartridge provided by manufacturer. The extraction process run by the machine according to manufacturers' instruction. The results were obtained in approximately 105 minutes.

The viral load or HCV RNA values was quantified in $\log 10 \mathrm{IU} / \mathrm{mL}$. Correlation was performed by Pearson test, followed with regression liner test. Diagnostic test results were analyzed with Chi-square test. Sensitivity and specificity of the GeneXpert assay compared to Roche Cobas TaqMan 96 as gold standard measured by calculating $2 \times 2$ contingency table. Sensitivity of the GeneXpert defined as the ability of a test Genexpert identify those patients with $\mathrm{HCV}$ positive, whereas specificity of a test Genexpert defined as the ability of the test to correctly identify those patients with $\mathrm{HCV}$ negative. Bland-Altman plot were generated to assess mean difference between the two assays. All data were analyzed using SPSS (version 23).

\section{RESULTS}

From total $45 \mathrm{HCV}$-infected with detectable viral load subjects participated in our study, most of them was male $(55 \%)$, while in a total 9 subjects within negative control also dominantly with male (66\%). A total of 54 plasma samples, including nine negative control samples, were available for comparative and correlative analysis. Median value of viral load quantification in GeneXpert was lower compared to Cobas TaqMan 96 result $\left(2.72 \times 10^{5} \mathrm{IU} / \mathrm{mL}\right.$ vs. $3.04 \mathrm{x}$ $10^{5} \mathrm{IU} / \mathrm{mL}$ respectively).

The mean value of inter assay viral load quantification is described in Table 1. Based on the median values of GeneXpert and Roche Cobas TaqMan 96, there was no differences between HCV RNA value in each assay.
It was shown that viral load value in Roche Cobas TaqMan 96 at $2 \log$ through $6 \log$ were higher than in GeneXpert. The difference in these result was not exceeding $1 \log$ limit. There was significant strong correlation between two assays $(\mathrm{R}=0.993, \mathrm{p}=0.001)$. Linier regression analysis was performed to shown the distribution of each viral load in both af assay, with $\mathrm{y}=$ $0.95 \mathrm{x}+0.14$ (Figure 2).

Of 54 samples, the nine negative control samples detected as negative both in GeneXpert and Roche Cobas TaqMan 96. Amongst 45 positive samples in GeneXpert, 1 sample was detected as negative by Roche Cobas TaqMan 96 (Table 2). The GeneXpert HCV viral load assay shown to has sensitivity of 100\% (95\% CI: 90-100\%) and specificity of $90 \%$ (95\% CI: $54.1-99.5 \%)$ with the positive predictive value (PPV) of $97.7 \%$ (95\% CI: $86.8 \%-99.9 \%$ ), and the negative predictive value (NPV) of $100 \%$ (95\% CI: $62.9 \%-100 \%)$.

The differences of tolerable HCV RNA value in the two assays is determined by a limit of $<1 \log$ IU/ $\mathrm{mL}$. The majority of the samples were within $<1 \log$ difference, except one sample that has 1 log difference with the Roche Cobas TaqMan 96 measurement result. This one sample has HCV RNA value $<10 \mathrm{IU} / \mathrm{mL}$ that could still be detected by GeneXpert while in Roche

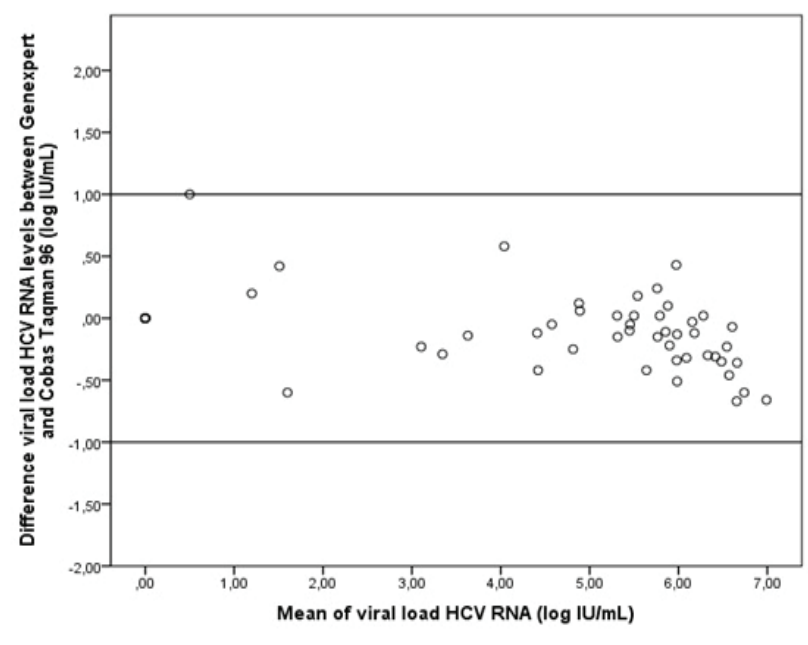

Figure. 1. Bland-Altman plot analysis of quantification of HCV RNA levels in GeneXpert and Roche Cobas TaqMan 96 assay. HCV, Hepatitis C Virus; RNA, ribonucleic acid

Table 1. Quantitative results of viral load in GeneXpert and Cobas TaqMan 96.

\begin{tabular}{ccc}
\hline $\begin{array}{c}\text { HCV RNA values } \\
\text { (log IU/mL) }\end{array}$ & \multicolumn{2}{c}{ Average of viral load value (log10 IU/mL) } \\
\cline { 2 - 3 } & GeneXpert & Roche Cobas TaqMan 96 \\
\hline 1 & 1.33 & 1.07 \\
2 & 2.99 & 3.22 \\
3 & 3.38 & 3.60 \\
4 & 4.57 & 4.58 \\
5 & 5.66 & 5.77 \\
6 & 6.34 & 6.60 \\
\hline
\end{tabular}

IU: international unit; $\mathrm{mL}$ : mililitre. 


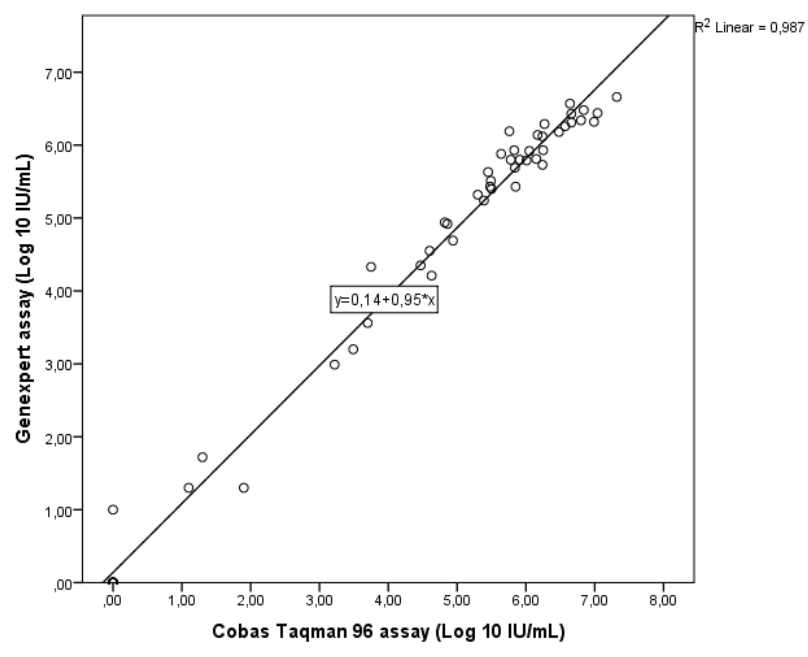

Figure 2. Regression linier analysis for distribution of each samples in both of assay.

Table 2. Qualitative results of viral load in GeneXpert and Roche Cobas TaqMan 96.

\begin{tabular}{lccc}
\hline \multirow{2}{*}{ GeneXpert } & \multicolumn{2}{c}{ Roche Cobas TaqMan 96 } & \\
\cline { 2 - 3 } & $\begin{array}{c}\text { Virus } \\
\text { detected } \\
\mathbf{n ~ ( \% )}\end{array}$ & $\begin{array}{c}\text { Virus not } \\
\text { detected } \\
\mathbf{n ~ ( \% )}\end{array}$ & $\begin{array}{c}\text { Total } \\
\mathbf{n ~ ( \% ) ~}\end{array}$ \\
\hline Virus detected & $44(100)$ & $1(10)$ & $45(83)$ \\
Virus not & $0(0)$ & $9(90)$ & $9(17)$ \\
detected & & $10(100)$ & $54(100)$ \\
\hline Total & $44(100)$ & & \\
GeneXpert sensitivity & $=44 / 44 \times 100 \%=100 \%(95 \% \mathrm{Cl}: 90-100 \%)$ \\
GeneXpert specificity & $=9 / 10 \times 100 \%=90 \%(95 \% \mathrm{Cl}: 54.1-99.5 \%)$ \\
GeneXpert PVP & $=44 / 45 \times 100 \%=97.7 \%(95 \% \mathrm{Cl}: 86.8-999 \%)$ \\
GeneXpert PVN & $=9 / 9 \times 100 \%=100 \%(95 \% \mathrm{Cl}: 62.9-100 \%)$
\end{tabular}

Cobas TaqMan 96 it was undetectable (Fig.1.).

\section{DISCUSSION}

Two commercial PCR assays to measure HCV RNA, the Cobas TaqMan and the Abbott RealTime HCV test, are now widely available throughout the world. Based on tool's protocol, the lower limit of detection (LOD) of Cobas TaqMan $96 \mathrm{HCV}$ test is 8.46 to 12.58 for EDTA plasma sampels, depend on what genotype being detected. Abbott RealTime PCR HCV test per se has $12 \mathrm{IU} / \mathrm{mL}$ as its LOD. Based on study by Vermehren et al, Cobas TaqMan and Abbott RealTime PCR HCV test have a good concordance in quantifying HCV RNA in 323 samples. ${ }^{10}$ Our study compares GeneXpert performance against Cobas TaqMan 96 as standard tool for HCV viral load measurements in 36 patients' plasma samples. Both intruments are fully automated real-time PCR assay. To our knowledge, this is the first study to evaluate the sensitivity and specificity of GeneXpert for quantification of $\mathrm{HCV}$ RNA in Indonesia.

The median value and maximum viral load value detected in GeneXpert was lower compared to Cobas
TaqMan 96. In this table, we reported the value in median due to abnormal distribution, hence the confidence intervals for the observed results were not presented. Based on WHO report, GeneXpert has lower LOD than Cobas TaqMan in detection of all genotypes (4.19 IU/mL [95\% CI: $3.17-10.69 \mathrm{IU} / \mathrm{mL}]) .{ }^{9} \mathrm{As}$ EASL recommendation of $\mathrm{HCV}$ management, GeneXpert has met the criteria of standard LOD for HCV RNA detection $(\leq 15 \mathrm{~mL}){ }^{4}$

The mean of viral load value between the GeneXpert and Cobas TaqMan assay were not much different (Table 1) and the correlation between two assays' value were significant $(\mathrm{R}=0.993, \mathrm{p}=0.001)$. This result is in line with study by Maleska et al, who reported a good correlation between Cepheid Xpert HCV Viral Load assay and Cobas AmpliPrep/Cobas TaqMan HCV Test in quantification of HCV viral load using plasma speciment $(\mathrm{R}=0.984) .{ }^{11}$ Study by McHugh et al with 636 HCV-infected sampels demonstrate that Xpert HCV Viral Load quantifies viral load accurately in comparison to Abbott RealTime HCV assay as the gold standard. ${ }^{12}$ Other study by Gupta et al with $118 \mathrm{HCV}$ infected plasma samples also demonstrate similar good correlation result between Xpert and Abbott assay. ${ }^{8}$

Bland-Altman plot analysis (Figure 1) showed one sample with $1 \log \mathrm{IU} / \mathrm{mL}$ difference. There was one sample in lowest viral load value that was not detected in Cobas TaqMan while it was detected in very low level $(<10 \mathrm{IU} / \mathrm{mL})$ by GeneXpert. This could be a false positive result but we did not re-tested this discrepant result in Cobas TaqMan. One study about Cobas TaqMan performance by Chevaliez et al suggested two technical issues that might be occur by using the instrument and kit for quantifying HCV RNA, such as underestimate HCV RNA levels in particular genotype or overestimate HCV RNA levels in undiluted samples by around $0.6 \log 10 \mathrm{IU} / \mathrm{mL} .^{13}$ Here, we suspected that the sample's viral load titer might not met lower limit of quantification (LLOQ) for both assays but still met lower limit of detection of GeneXpert. Strassl et al analyse the sensitivity of commercially HCV RNA quantification instrument: Roche Cobas AmpliPrep/Cobas TaqMan Version 1, Version 2, and Abbott RealTime. There was overall good concordance between Cobas TaqMan Version 1 and 2. However, both version of Cobas TaqMan detected serum samples as negative while it was detected by Abbott RealTime. The LLOQ of Cobas TaqMan Version 1 and Version 2 is approximately 15 $\mathrm{IU} / \mathrm{mL}$, which were higher in comparison to Abbott RealTime assay with $12 \mathrm{IU} / \mathrm{mL} .{ }^{14}$ Similar study by 
Moritou et al reported similar discrepancies, where the HCV-infected serum samples detected as negative by Cobas TaqMan Version 1 turn out to be detected by Abbott RealTime. Undetectable HCV RNA in Cobas TaqMan might require reassessment. ${ }^{15}$ There was also a chance that the HCV RNA quantification result is genotype-related and each instruments, particularly from study by Pierce et al with Cobas TaqMan Version 1 and 2 , interpret it differently. ${ }^{16}$

The nine negative control samples detected as negative in both GeneXpert and Roche Cobas TaqMan 96 assay, while $45 \mathrm{HCV}$-infected samples detected as positive in GeneXpert assay except one which was negative in Roche Cobas TaqMan 96 (Table 2). Lamoury et al reported that Xpert shown to has high sensitivity and specificity for quantification of HCV RNA. ${ }^{5}$ Grebely et al stated identical result, where the sensitivity for Xpert HCV Viral Load assay of the venepunctured plasma was 100\% (95\% CI: $92-100 \%$ ) and the specificity was $99.1 \%$ (95\% CI: 94.9-100\%). The result does not differ much from our study, where the sensitivity and specificity analysis of GeneXpert with plasma speciments yield the number of $100 \%$ (95\% CI: $90-100 \%)$ and $90 \%$ (95\% CI: $54.1-99.5 \%)$ respectively. ${ }^{17}$

Meanwhile, the sensitivity of the capillary fingerstick sampels in Xpert HCV Viral Load assay from Grebely et al study was $95.5 \%$ (95\% CI: 84.5-99.4\%) and the specificity was $98.1 \%$ (95\% CI: 93.4-99.8\%). The sensitivity and specificity of both finger-stick and venepunctured speciment with Xpert assay reported to be all good compared to standard diagnostic tool (Abbott RealTime HCV RNA). ${ }^{17}$ Hence, the use of GeneXpert for HCV viral load testing is promising, both in plasma or serum speciment. In the era of direct acting antiviral (DAA), the need for HCV RNA quantification is required for diagnosis and treatment response monitoring. The qualitative $\mathrm{HCV}$ RNA examination, as well as the examination of the HCV core antigen, has the potential to be utilized.

In terms of efficiency, although a little bit higher specimen volume is required compared to Roche Cobas TaqMan, Xpert HCV Viral Load assay' has shorter hands-on time, no need for a large space, and able to provide result faster. ${ }^{9}$ In terms or costeffectivity, the cost for running the test is constant per result, independent of daily volume. ${ }^{18} \mathrm{HCV}$ RNA quantification by GeneXpert has not been commercialized in our country. For comparison, in our center, HCV RNA quantification by Cobas TaqMan 96 cost IDR 900,000 to 2,000,000 ( USD 64 to 142 ) per one patient's sample. While with Xpert, according to other study by McHugh et al, cost EUR 35 ( $\sim 40$ USD) per test cartridge. ${ }^{12}$ Considering its simplicity and shorter turnaround time, Xpert HCV Viral Load testing seems well suited for rapid diagnosis of $\mathrm{HCV}$ infection and routine treatment monitoring in areas of limited facilities.

This study has limitation. Since the study was conducted in one center, this study could not be generalize in general population. Therefore, validation of studies are needed to evaluate Genexpert in different setting. The result of correlation, sensitivity, and specificity GeneXpert was good, inspite of the sample size of this study was limited. For the detection of HCV RNA viral load, a finger-stick might also promising as HCV RNA assay in the future.

\section{CONCLUSION}

This study was a preliminary in Division of Hepatobilary, Cipto Mangunkusumo National Hospital, which later can be applied in limited facility areas as an alternative standard diagnostic tools. Based on our study, there was strong correlation between GeneXpert and Cobas TaqMan 96 for quantification and qualification of HCV RNA levels in our subject population. GeneXpert has overall excellent sensitivity, specificity, and give more rapid result in addition to be expectedly cost-effective.

\section{ACKNOWLEDGEMENTS}

We thank to Ms. Anugrah Dwi Handayu for helping of PCR analyses, and Ms. Gita Aprilicia who helped in datasets and analyses.

\section{REFERENCES}

1. Mohd Hanafiah K, Groeger J, Flaxman AD, Wiersma ST. Global epidemiology of hepatitis $\mathrm{C}$ virus infection: new estimates of age-specific antibody to HCV seroprevalence. Hepatology 2013;57:1333-42.

2. Polaris Observatory HCVC. Global prevalence and genotype distribution of hepatitis $C$ virus infection in 2015: a modelling study. Lancet Gastroenterol Hepatol 2017;2:161-76.

3. Easterbrook PJ, Group WHOGD. Who to test and how to test for chronic hepatitis C infection - 2016 WHO testing guidance for low- and middle-income countries. J Hepatol. 2016;65(1 Suppl):S46-66.

4. European Association for the Study of the Liver. Electronic address eee. EASL recommendations on treatment of Hepatitis C 2016. J Hepatol 2017;66:153-94.

5. Lamoury FMJ, Bajis S, Hajarizadeh B, Marshall AD, Martinello M, Ivanova E, et al. Evaluation of the Xpert $\mathrm{HCV}$ viral load finger-stick point-of-care assay. J Infect Dis 2018;217:1889-96. 
6. Cloherty G, Talal A, Coller K, Steinhart C, Hackett J, Dawson $\mathrm{G}$, et al. Role of serologic and molecular diagnostic assays in identification and management of Hepatitis $\mathrm{C}$ virus infection. J Clin Microbiol 2016;54:265-73.

7. Omata M, Kanda T, Wei L, Yu ML, Chuang WL, Ibrahim A, et al. APASL consensus statements and recommendations for hepatitis $\mathrm{C}$ prevention, epidemiology, and laboratory testing. Hepatol Int 2016;10:681-701.

8. Gupta E, Agarwala P, Kumar G, Maiwall R, Sarin SK. Pointof-care testing (POCT) in molecular diagnostics: Performance evaluation of GeneXpert HCV RNA test in diagnosing and monitoring of HCV infection. J Clin Virol 2017;88:46-51.

9. WHO. WHO Prequalification of In Vitro Diagnostics. 2017.

10. Vermehren J, Aghemo A, Falconer K. Clinical significance of residual viremia detected by two real-time PCR assays for response-guided therapy of HCV genotype 1 infection. J Hepatol 2014;60:913-9.

11. Maleska A, Mondain AM, Ottomani L, Ducos J. Xpert HCV viral load RT-PCR assay (Cepheid) for urgent sample hepatitis $\mathrm{C}$ virus quantification. Poster session presented at the 26th European Congress of Clinical Microbiology and Infectious Diseases, European Society of Clinical Microbiology and Infectious Diseases, Amsterdam, Netherlands 2016.

12. McHugh MP, Wu AHB, Chevaliez S, Pawlotsky JM, Hallin M, Templeton KE. Multicenter Evaluation of the Cepheid Xpert Hepatitis C Virus Viral Load Assay. J Clin Microbiol 2017;55(5):1550-6.

13. Chevaliez S, Bouvier-Alias M, Brillet R, Pawlotsky JM. Overestimation and underestimation of hepatitis C virus RNA levels in a widely used real-time polymerase chain reactionbased method. Hepatology 2007;46:22-31.

14. Strassl R, Rutter K, Stattermayer AF, Beinhardt S, Kammer M, Hofer H, et al. Real-Time PCR Assays for the Quantification of HCV RNA: Concordance, Discrepancies and Implications for Response Guided Therapy. PLoS One 2015;10:e0135963.

15. Moritou Y, Ikeda F, Takeuchi Y, Seki H, Nanba S, Iwasaki Y, et al. Necessity for reassessment of patients with serogroup 2 hepatitis $\mathrm{C}$ virus (HCV) and undetectable serum HCV RNA. J Clin Microbiol 2014;52:544-8.

16. Pierce VM, Eversley JS, Tran TK, Rosenberg ES. Differences between quantification of genotype 3 hepatitis $\mathrm{C}$ virus RNA by Versions 1.0 and 2.0 of the COBAS AmpliPrep/COBAS TaqMan HCV Test. Clin Chem Lab Med 2017;55:956-61.

17. Grebely J, Lamoury FMJ, Hajarizadeh B, Mowat Y, Marshall $\mathrm{AD}$, Bajis S, et al. Evaluation of the Xpert HCV Viral Load point-of-care assay from venepuncture-collected and fingerstick capillary whole-blood samples: a cohort study. Lancet Gastroenterol Hepatol 2017;2:514-20.

18. Iwamoto M, Calzia A, Dublineau A, Rouet F, Nouhin J, Yann $\mathrm{S}$, et al. Field evaluation of GeneXpert ${ }^{\circledR}$ (Cepheid) HCV performance for RNA quantification in a genotype 1 and 6 predominant patient population in Cambodia. J Viral Hepat 2019;26:38-47. 